\title{
A RESPONSE TO SCHILL AND WACHTER'S \\ THE SPATIAL BIAS OF FEDERAL \\ HOUSING LAW AND POLICY
}

\section{GeORGE GALSTER $\dagger$}

In their article, The Spatial Bias of Federal Housing Law and Policy: Concentrated Poverty in Urban America, ${ }^{1}$ Professors Michael Schill and Susan Wachter provide a careful, scholarly critique of palpable policy relevance. Their analysis reflects the consistent pattern that their past productive collaboration has established: a thoughtful amalgam of legal, historical, economic, and statistical expertise that yields provocative conclusions. It is thus my privilege to have the opportunity to comment upon it.

The fundamental claim of Schill and Wachter's article is that past and current federal housing law and policy (especially as they relate to public housing and mortgage markets) intensify the concentration of low-income families in inner-city neighborhoods, either intentionally or unintentionally. ${ }^{2}$ Fortunately, they argue, many of these mistakes are capable of remediation through new federal initiatives.

Much of the historical evidence Schill and Wachter offer to support their claim is compelling. Although this is familiar territory to scholars, as Schill and Wachter's footnotes show, the authors present the material succinctly and powerfully. To their credit, they bring to bear econometric methods to supplement the historical analysis, and find evidence related to the geography of public housing and the rejection patterns of mortgage lenders that they claim buttress their case.

My response to Schill and Wachter's analysis essentially is that important aspects of their argument are either conceptually and/or empirically inconclusive. Furthermore, their discussion of "current" federal housing policy pays insufficient attention to recent initiatives of the Clinton Administration that go a long way in the directions advocated by the authors. I will first consider Schill and Wachter's arguments that relate to public housing, then those that relate to

† Principal Research Associate, Director of Housing Research, The Urban Institute.

${ }^{1}$ Michael H. Schill \& Susan M. Wachter, The Spatial Bias of Federal Housing Law and Policy: Concentrated Poverty in Urban America, 143 U. PA. L. REV. 1285 (1995).

${ }^{2}$ See id. at 1285. 
the Community Reinvestment Act. Finally, I will discuss policy implications.

\section{Public Housing AND NeIgHBorhood EXTERNALITIES}

Schill and Wachter note several plausible means by which past public-housing siting, tenant, and maintenance policies could have intensified the concentration of poor families in central cities. One set of reasons is almost tautological: given that high-density publichousing complexes were built in neighborhoods that already had above-average poverty concentrations and were inhabited predominantly by poor families, observed rates of poverty must be higher in such neighborhoods. ${ }^{3}$ The other set of reasons is behavioral and involves unsubsidized households. At root, Schill and Wachter argue that concentrations of public housing create a variety of negative externalities for the surrounding environs. Such externalities might reasonably be expected to induce nonpoverty families to move from the area and deter others from moving in, depress property values, and encourage property owners to defer maintenance and to subdivide dwellings into smaller rental units. All this should lead to an increase in the proportion of poor families residing in the private housing stock near public housing. ${ }^{4}$

To test this proposition, Schill and Wachter specify and estimate a logit model for post-World War II Philadelphia census tracts. They find that, ceteris paribus, tracts with a larger share of public housing in their neighborhood dwelling stock at the beginning of a decade have a significantly higher ratio of poor to nonpoor families by the end of that decade. They correctly note that this statistical result is consistent with their hypothesis of neighborhood externalities. $^{5}$

My response would be twofold. First, the externality interpretation is inconsistent with the body of evidence (cited by Schill and Wachter) that fails to find lower property values near public-housing projects. Second, there are two alternative (not mutually exclusive) explanations for the Schill-Wachter statistical result that do not involve externalities and are consistent with the aforementioned property value studies: increasing concentrations of poverty within

\footnotetext{
${ }^{9}$ Unless, of course, the number of poor families displaced in order to construct the public housing exceeded those eventually housed in such housing.

${ }^{4}$ See Schill \& Wachter, supra note 1 , at 1300-08.

${ }^{5}$ See id. at 1301-07.
} 
public-housing projects themselves and massive abandonment of the private housing stock that was unrelated to public housing.

The first scenario was alluded to by Schill and Wachter: during the post-war period, public-housing occupancy rules increasingly targeted the poorest of the poor and rendered working families ineligible. ${ }^{6}$ Thus, even with no impact on the private stock nearby, the presence of public housing could prove statistically associated with rising ratios of poor to nonpoor families. Some hypothetical data to illustrate this claim are presented in Scenario 1 in Table I. It compares two neighborhoods, $\mathrm{A}$ and $\mathrm{B}$, that are identical in every respect (including beginning of period poverty/nonpoverty ratios) except the share of the stock comprised of public housing. Here, if the poverty tenancy in the four hypothetical public-housing units were to rise from two to four over the decade, the neighborhood poverty/nonpoverty ratio would rise from .67 to 1.5 , even with no change in private stock there.

The second explanation is traced to the massive population and housing stock losses associated with a bevy of region- and metropolitan-wide forces relating to transportation, technology, and industrial restructuring. ${ }^{8}$ Indeed, the City of Philadelphia's occupied housing stock declined from a peak of 642,145 in $1970^{\circ}$ to 603,075 in $1990,{ }^{10}$ a loss of six percent. Such residential abandonment would have displaced poor and nonpoor families from neighborhoods where it occurred; ironically, because public housing was more resistant to abandonment but was disproportionately occupied by poor tenants, its presence in a neighborhood with private abandonment would yield a larger statistical increase in poverty/nonpoverty ratios, even if there were no causal link. This process is illustrated with Scenario 2 in Table I. ${ }^{11}$ Assume that privately owned units in both neighborhoods $A$ and $B$ have both poor and nonpoor residents at the beginning of the decade and that in both neighborhoods half the private stock is abandoned (equally affecting both poor and nonpoor, for simplicity). Because the poor families in public housing in neighborhood A remain constant, but the population of

${ }^{6}$ See id. at 1294.

7 See id. at 1287.

${ }^{8}$ See id. at 1311 n.104.

${ }^{9}$ See U.S. DeP'T OF Commerce, Bureau of Census, Detailed housinc Characteristics: PENNSYlVANia tbl. 31 (1970).

${ }^{10}$ See U.S. Dep'T OF Commerce, Bureau of Census, General housinc ChaRACTERISTICS: PENNSYLVANIA tbl. 1 (1992).

"See Schill \& Wachter, supra note 1, at 1287. 
nonpoor families has been reduced in A through abandonment, one observes a higher poverty/nonpoverty ratio by the end of the decade.

\section{Community Reinvestment ACt AND POVERTY CONCENTRATION}

Schill and Wachter argue that federal mortgage lending regulatory policies as embodied in the Community Reinvestment Act (CRA) have unintended negative consequences for low-income neighborhoods. To the extent that the CRA induces lenders to take undue risks in accepting the applications for those seeking to buy or improve properties in lower-income neighborhoods, it could unwittingly foment the sort of concentrated defaults and neighborhood blight that characterized the Section 235 program of the 1970 s. $^{12}$

Although the logic is attractive, the authors provide no evidence that the CRA has had such an impact. Others have argued that "CRA loans" are no riskier than standard loans. Rather, a variety of biases, information shortcomings, and market failures have been responsible for lenders' past shortcomings in these areas, problems that can only be overcome through the impetus of the CRA. ${ }^{13}$ Indeed, the enhanced flow of funds may improve both efficiency and equity, and may induce a variety of positive synergisms among homeowners' expectations, mobility, and property reinvestment. ${ }^{14}$

Even less persuasive is Schill and Wachter's claim that enforcement of the CRA intensifies the spatial concentration of poverty because financial institutions may be encouraged to make loans to marginally qualified (that is, poor) borrowers when they try to buy homes in predominately poor neighborhoods. ${ }^{15}$ To test for this "loan concentration effect," Schill and Wachter use 1991 Boston data to estimate a model of mortgage application acceptances and rejections. ${ }^{16}$ They find that borrowers with income less than eighty percent of metropolitan area median are more likely to be rejected

${ }^{12}$ See id. at 1312-13.

${ }^{13}$ See Charles W. Calomiris et al., Housing-Finance Intervention and Private Incentives: Helping Minorities and the Poor, 26 J. MONEY, CREDIT \& BANKING 634-74 (1994); see also William W. Lang \& Leonard I. Nakamura, A Model of Redlining, $33 \mathrm{~J}$. URB. ECON. 223 (1993).

${ }^{14}$ See generally GeORGE GALSTER, HOMEOWNERS AND NEIGHBORHOOD REINVESTMENT (1987).

${ }^{15}$ See Schill \& Wachter, supra note 1, at 1320-25.

${ }^{16} I d$. at $1325-28$. 
when they apply to purchase property in census tracts having median incomes greater than eighty percent of the metropolitan median, ceteris paribus. ${ }^{17}$

I find the foregoing argument untenable for two overarching reasons. First, if we accept for the moment that the CRA was causing lenders to undertake unproductively risky activities vis-à-vis low-income neighborhoods (as opposed to individuals), we should observe that denial rates were lower for any applicants who were attempting to purchase homes in lower-income neighborhoods, ceteris paribus. Schill and Wachter's model provides such a test, ${ }^{18}$ and precisely the opposite result is evinced. Second, how can such statistical results, no matter what patterns they demonstrate, be convincingly traced to the CRA? Inasmuch as the Boston data analyzed here were collected before the recently intensified enforcement efforts by the federal financial institution regulatory agencies and the Justice Department, they reveal as much about the earlier inadequate enforcement of the CRA than its supposedly potent (if perverse) effects. Indeed, when originally analyzed by researchers at the Federal Reserve Bank of Boston, the data employed by Schill and Wachter were used to demonstrate that equally qualified minorities were denied for mortgage applications at a rate sixty percent higher than whites. ${ }^{19}$ Surely a testimony to lax enforcement!

\section{POLICY IMPLICATIONS}

Schill and Wachter make many recommendations for revising federal policy with which I heartily agree. In contrast to their specific and detailed recommendations for revising Section 8 and public-housing regulations, however, their generalities about needing to enhance civil rights enforcement stand in stark contrast. $^{20}$ They are also conspicuously silent on the CRA. If it is as bad as they suggest, how should it be modified?

Elsewhere I have analyzed what is needed for more effective civil rights enforcement in housing and lending markets. ${ }^{21}$ Suffice it to

${ }^{17}$ See id. at 1327-28.

${ }^{18}$ That is, the coefficient of the NLOWAREA variable. See Schill \& Wachter, supra note 1 , at $1326-27$.

${ }^{19}$ See id. at 1330.

${ }^{20}$ See id. at 1329-33.

${ }^{21}$ See George Galster, The Great Misapprehension: Federal Fair Housing Policy in the Eighties, in BuILding Foundations: HOUSING AND FEderal POLICY 137 (Denise 
note the bottom line: systemic, pattern and practice investigations conducted with paired testers posing as home- or mortgage-seekers are required. ${ }^{22}$ The difficulties of formulating and enforcing effective CRA regulations are more troubling and well beyond the scope of this Paper. ${ }^{23}$

As a final point, I find Schill and Wachter's policy conclusions unbalanced inasmuch as they do not pay sufficient attention to numerous initiatives to deconcentrate poverty promulgated by the Clinton Administration. In the area of fair housing enforcement, HUD has increased the funding for the Fair Housing Initiatives Program from $\$ 11$ million in fiscal year 1993 to $\$ 26$ million in fiscal year 1995, and the Justice Department has significantly intensified its fair housing and fair lending litigations. ${ }^{24}$ In the area of expanding affordable housing opportunities, HUD has already proposed several of the modifications suggested by Schill and Wachter (increased portability, repeal of the nondiscrimination clause, and pro-mobility counseling ${ }^{25}$ through the Choice in Residence program) in the Housing and Community Development Act of 1994 (which failed to pass in the 103d Congress). Finally, in the area of public housing, HUD has resolved several longstanding desegregation suits with the use of pro-mobility counseling and rent vouchers. HUD has granted waivers permitting the mixing of tenants and use of vouchers as "replacement units" for public housing that has been demolished. If the HUD Reinvention Blueprint becomes law, this trend of deconcentrating and revitalizing public housing will be intensified. ${ }^{26}$

DiPasquale \& Langley Keyes eds., 1990).

${ }^{22}$ Although this may have some limitations past the mortgage pre-application stage. For more on the difficulties of bank examinations detecting disparate treatment discrimination, see George Galster, Future Directions in Mortgage Discrimination Research and Enforcement (paper presented at the HUD Home Lending and Discrimination Conference, June 1993) (on file with author).

${ }^{23}$ See George Galster, Evaluation of Proposed CRA Regulations: The Lending Test (Urban Institute Report No. 6466, 1994) (on file with author).

${ }^{24}$ See George Galster, Minority Poverty: The Place-Race Nexus and the Clinton Administration's Civil Rights Policy, in NEw CHALlenges: THE CIVIL RIGHTS RECORD OF THE CLINTON ADMINISTRATION MID-TERM 31 (Corrine Yu \& William Taylor eds., 1994).

${ }_{25}$ Pro-mobility counseling is a service provided by housing authorities that assist tenants in moving to neighborhoods that are less affected by poverty.

${ }^{26}$ See U.S. Dep't of Hous. and Urban Dev., Reinvention Blueprint (internal HUD memorandum, Dec. 1994) (on file with author). 


\section{CONCLUSION}

Federal housing law and policy has undoubtedly contributed to the concentration of poor families in our inner-city areas. But the historical record of case documentation remains more convincing than the record of statistical modeling, despite the laudable, pathbreaking investigations conducted by Schill and Wachter.

But such quibbles among scholars are merely a side show; it will be much more intriguing to watch how Schill and Wachter's article (and others in the same genre) ${ }^{27}$ will be used as ammunition in the contemporary political process. Liberals may seize upon it as a rationale for remedial federal intervention: "Take responsibility to clean up the mess you made." Conservatives could utilize it to justify diminishing the federal role in housing policy: "You messed up before, how can you be trusted again?"

${ }^{27}$ See e.g., DOUGlas S. MASSEy \& NANCY A. DENTON, AMERICAN APARTHEID: SEGREgatION AND THE MAKING OF THE UNDERCLASS (1993). 
